DOI: https://doi.org/10.47405/mjssh.v5i10.514

\begin{tabular}{|c|c|}
\hline 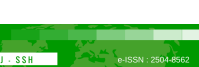 & Malaysian Journal of Social Sciences and Humanities (MJSSH) \\
\hline $\begin{array}{l}\text { Malaysian Journal of } \\
\text { socal sciences and }\end{array}$ & Volume 5, Issue 10, October 2020 \\
\hline (MJ-SSH) & e-ISSN : 2504-8562 \\
\hline & $\begin{array}{l}\text { Journal home page: } \\
\text { www.msocialsciences.com }\end{array}$ \\
\hline
\end{tabular}

\title{
Analisis Instrumen Pengukuran Kebahagiaan Guru: Sorotan Literatur Bersistematik
}

\author{
Kartini Wan Mat' ${ }^{1}$, Mohd Effendi @ Ewan Mohd Matore ${ }^{1}$ \\ 1Fakulti Pendidikan, Universiti Kebangsaan Malaysia (UKM) \\ Correspondence: Mohd Effendi @ Ewan Mohd Matore (effendi@ukm.edu.my)
}

\begin{abstract}
Abstrak
Penerapan kebahagiaan pelajar bermula dengan penerapan kebahagiaan guru dalam kehidupan. Kajian lepas menunjukkan tahap kebahagiaan guru dilihat berpotensi dalam mempengaruhi tahap kebahagiaan seseorang pelajarnya. Oleh itu, objektif dalam melahirkan individu yang bahagia memerlukan seorang guru yang memiliki tahap kebahagiaan yang tinggi. Justeru, kajian ini dilaksanakan untuk menganalisis instrumen pengukuran kebahagiaan guru berdasarkan kaedah sorotan literatur sistematik (SLR). Selain itu, kajian ini turut meneliti instrumen yang sesuai untuk mengukur tahap kebahagiaan guru di Malaysia dan mengkaji konstruk dalam instrumen mengukur kebahagiaan guru. Kajian ini telah mengenal pasti sepuluh instrumen pengukur kebahagiaan sebagai fokus pasca saringan literatur. Pemilihan dijalankan dengan proses mengenal pasti instrumen seperti penetapan kata kunci, pemilihan pangkalan data dan penetapan set kriteria. Model PRISMA digunakan sebagai panduan dalam pencarian bahan literatur. Setiap sepuluh instrumen telah dikategorikan mengikut kegunaan, kekuatan, kelemahan, jumlah item dan konstruk. Kajian telah mengenal pasti lima sahaja instrumen yang berpotensi dalam mengukur kebahagiaan guru di Malaysia daripada sepuluh instrumen tersebut. Daripada lima instrumen yang di senaraikan, empat instrumen sahaja yang sesuai digunakan untuk guru di Malaysia dalam mengukur kebahagiaan guru secara menyeluruh. Kajian ini mencadangkan agar kajian lanjutan dibuat berkaitan pengukuran kebahagiaan dalam kalangan guru matematik. Hal ini berdasarkan batasan kajian iaitu tiada kajian kebahagiaan guru mengikut subjek yang diajari.
\end{abstract}

Kata kunci: kebahagiaan, sorotan literatur bersistematik, guru, instrumen, pengukuran

\section{Measurement Analysis of Teacher Happiness Instrument: Systematic Literature Review}

\begin{abstract}
The application of student happiness begins with the application of the teacher's happiness in life. The previous studies show that the level of teacher's happiness is seen as potential in influencing the level of student's happiness. Therefore, producing a happy individual requires a teacher who has a high level of happiness. Thus, this study was conducted to analyse the instrument that measures the happiness of teachers based on the systematic literature review (SLR) method. Besides, this study also examines the instruments that suitable to measure the level of happiness of teachers in Malaysia and also examines the constructs in instruments that specifically measure teachers' happiness. This study has identified ten happiness measuring instruments as a post-screening focus of literature. Selection is carried out by the process of identifying instruments such as keyword setting, database selection and setting criteria. The PRISMA model is used as a guide in the literature search process. Each of the ten instruments was
\end{abstract}


categorized according to their uses, strengths, weaknesses, number of items and constructs. The study has identified that out of ten instruments, only five instruments which potential in measuring the teacher's happiness in Malaysia. Out of the five instruments listed, only four instruments are suitable for teachers in Malaysia to used to measure the comprehensive teacher's happiness. This study suggests that further research be done related to the measurement of happiness among mathematics teachers. This recommendation is based on the limitations of the study, which shows that there is no study on the happiness of teachers according to the subjects they taught.

Keywords: happiness,systematic literature review,teacher,instrument, measurement

\section{Pengenalan}

Bahagia ialah sesuatu perkara yang terlalu subjektif untuk dinilai. Kebahagiaan setiap manusia bergantung kepada manusia itu sendiri untuk mendefinisikan bahagia mengikut kehendak mereka sendiri. Bahagia manusia juga tidak bergantung kepada keadaan semasa tetapi juga mengambil kira kepada pengalaman masa lampau yang dilalui dan matlamat masa hadapan manusia tersebut (Krishna 2016). Konsep kebahagiaan telah wujud pada zaman Aristotle lagi. Pada zaman itu, Aristotle menggunakan perkataan Eudaimonia untuk menggambarkan kebahagiaan. Eudaimonia berasal daripada perkataan Yunani kuno yang bermaksud 'kehidupan yang baik' atau 'perkembangan manusia' (Clifton, 2014). Aristotle juga berpendapat bahawa kehidupan ialah renungan daripada eudaimonia yang sempurna dan bersifat transenden iaitu di luar kemampuan manusia normal kerana eudaimonia berunsurkan ketuhanan yang tinggi dalam diri individu (Awaludin, 2017). Dalam kajian Agrawal, Anjuli \& Tyagi (2016) menyimpulkan bahawa kebahagiaan pada definisi Aristotle ialah kebahagiaan ialah kehidupan yang bermakna serta bertujuan, matlamat yang menyeluruh dan pengakhiran kewujudan manusia.

Ideologi pemahaman Aristotle tentang kebahagiaan turut diakui oleh Seligman. Buktinya pada tahun 2002, Seligman telah membentangkan teori kebahagiaan yang hampir sama dengan ideologi Aristotle yang diberi nama sebagai authentic happiness (Seligman, 2004). Theory Authentic Happiness ataupun teori kebahagiaan autentik menekankan ideologi di mana kebahagiaan ialah memiliki kehidupan yang menyenangkan, kehidupan yang baik dan kehidupan yang bermakna. Manakala ahli ilmuwan Islam iaitu Al-Farabi pula mengatakan bahawa kebahagiaan ialah perkara yang di inginkan oleh jiwa manusia dalam kehidupan mereka, tiada yang lebih bermakna untuk di kecapi selain kebahagiaan dalam kehidupan. Al-Farabi juga berpendapat bahawa cara mengapai kebahagiaan ialah mengetahui segala kebenaran yang mungkin difahami oleh akal fikiran (Al-Farabi, 1995).

Dalam masa yang sama artikel yang ditulis oleh Ateerah dan Lukman (2019) menyatakan bahawa kebahagiaan ataupun sa'adah dalam sudut pandangan Islam ialah kebahagiaan bukan terbatas dengan sekadar dengan memiliki kehidupan yang baik, nikmat dan puas malahan kehidupan yang damai dan pengalaman kehidupan yang positif. $\mathrm{Sa}$ 'adah perkataan yang berasal daripada perkataan Arab yang membawa maksud kepada kebahagiaan. Dalam Islam, berdasarkan kitab Al-Quran dan Sunnah juga memberi penekanan yang penting dan besar dalam penerapan kebahagiaan dalam pelbagai aspek. Di samping itu, konteks kebahagiaan yang sebenar untuk seseorang individu ialah memiliki jiwa yang tenang, hati yang puas dan diri yang tenang (Ateerah \& Lukman, 2019). Tambahan, pandangan tentang kebahagiaan yang telah ditekankan oleh Al-Farabi hampir selari dengan pandangan Mahatma Gandhi yang berpendapat bahawa kebahagiaan ialah apabila perkara yang difikirkan oleh seseorang selari dengan perkara yang dikatakan dan perkara yang dilakukan olehnya (Agrawal, Anjuli \& Tyagi, 2016). Daripada pandangan dan pendapat yang dinyatakan oleh Al-Farabi dan Mahatma Gandhi, dapat disimpulkan bahawa seseorang individu akan berasa bahagia jika mereka dapat melakukan atau membuat perkara yang disukai dan atas kerelaan mereka sendiri.

Selain itu, kajian-kajian lepas seperti kajian Urrutia et al. (2019) mentakrifkan kebahagiaan ialah keadaan kesejahteraan mental dan emosi yang melibatkan emosi yang positif dan menyenangkan serta memuaskan. Satu lagi kajian yang dijalankan oleh Uchida dan Oishi (2016) telah mendefinisikan 
kebahagiaan yang hampir sama dengan kajian Urrutia et al. (2019) di mana kajian Uchida dan Oishi (2016) mendefinisikan kebahagiaan ialah keadaan atau perasaan puas seseorang individu terhadap kehidupan mereka.

Jadi daripada konsep dan ideologi kebahagiaan ini dapat disimpulkan bahawa kebahagiaan ialah sesuatu perkara yang boleh membuatkan individu berasa puas, tenang dan membangkitkan aura positif dalam diri individu sepanjang mereka menjalani kehidupan mereka. Dengan perasaan puas dan tenang ini akan mendorong kepada wujudnya kehidupan yang bermakna, bertujuan dan bermatlamat. Ini juga akan mewujudkan kedamaian dan keamanan dalam kehidupan seseorang individu.

\section{Kebahagiaan Terhadap Pendidikan dan Guru}

Pendidikan ialah sebuah platform utama untuk mengajar dan menyebarkan ilmu pengetahuan manakala sekolah, madrasah, gereja dan sebagainya ialah sebuah tempat tumpuan untuk menyebarkan ilmu pengetahuan. Oleh sebab itu, bagi menerapkan elemen-elemen kebahagiaan dalam diri setiap individu, bidang pendidikan sangat sesuai untuk dijadikan platform utama dalam mendidik seseorang. Setiap tingkah laku, tutur kata dan pemikiran seseorang bermula dengan pembelajaran. Sejak bayi lagi setiap individu memerlukan 'guru' untuk mereka belajar cara makan, berdiri, berjalan, bercakap dan cara berkomunikasi dengan betul (Michalos, 2017). Hal ini sama juga dengan konteks kebahagiaan yang memerlukan proses pembelajaran elemen bahagia dari sejak kecil lagi.

Lanjutan daripada itu, guru memainkan peranan penting dalam pembelajaran unsur kebahagiaan. Selain dalam merangsang intelektual pelajar, guru bertanggungjawab dalam mendidik pelajar dengan aktiviti-aktiviti fizikal seperti kegiatan sukan, persatuan dan kelab. Hal kerana aktiviti-aktiviti fizikal ini merupakan sebahagian daripada proses pembelajaran pelajar dalam mengawal emosi mereka dan pelajar juga dapat belajar cara berinteraksi dengan orang sekeliling mereka (Chaturvedi \& Singh, 2016). Oleh sebab guru adalah orang yang penting dalam menerapkan unsur kebahagiaan kepada pelajar, guru terlebih dahulu memerlukan kelebihan dalam memiliki unsur kebahagiaan ini. Kajian Erozkan et al. (2016) berpendapat bahawa individu yang memiliki tahap kebahagiaan yang lebih tinggi akan cenderung untuk mempunyai pemikiran yang lebih positif, memiliki kemahiran yang tinggi dalam mengawal tingkah laku dan keperibadian mereka serta menganggap pengalaman masa lampau ialah proses yang mematangkan diri mereka dan mereka juga akan lebih rasional dalam menghadapi situasi yang negatif dan positif.

Pandangan Erozkan et al. (2016) ini jelas menunjukkan bahawa guru yang memiliki tahap kebahagiaan yang tinggi mampu memberi aura yang positif kepada pelajar mereka kerana guru yang bahagia mampu menangani dan mengawal pelajar-pelajar mereka. Sepanjang proses pembelajaran dan pemudahcaraan $(\mathrm{PdPc})$ yang berlangsung di bilik darjah, guru merupakan orang yang berkuasa penuh dalam mengawal suasana dan persekitaran bilik darjah. Dengan semua isu yang dibangkitkan, tahap kebahagiaan guru antara perkara utama yang perlu ditekankan untuk mencapai objektif dalam melahirkan individu yang bahagia. Secara amnya, pengukuran dibuat untuk mengetahui dan membuktikan setiap perkara yang diukur secara tepat (Piaw, 2014). Jadi pengukuran kebahagiaan juga perlulah dilaksanakan untuk mengetahui tahap kebahagiaan guru terutamanya di Malaysia.

Menurut kajian yang dijalankan di luar negara, terdapat beberapa pengukuran kebahagiaan yang digunakan seperti The Authentic Happiness Inventory, Oxford Happiness Questionnaire, Subjective Happiness Scale dan banyak lagi. Kebanyakan pengukuran ini adalah bertujuan untuk mengukur kebahagiaan individu sama ada mengukur kebahagiaan individu di tempat kerja sahaja ataupun mengukur kebahagiaan individu merangkumi keseluruhan kehidupan mereka.

Manakala kajian yang dijalankan di Malaysia, kebanyakan pengkaji menggunakan instrumen seperti iOpener People Performance Questionnaire (iPPQ) dan Organizational Happiness Index (OHI) dalam mengukur tahap kebahagiaan (Abdullah, Ling, \& Ping, 2016; Abdullah, Ling, Ping, et al., 2016; Abdullah \& Ling, 2016b, 2016a; Omar et al., 2016, 2018). Bagi mengukur tahap kebahagiaan guru hanya instrumen $\mathrm{PPQ}$ yang digunakan sementara instrumen OHI pula tidak pernah digunakan untuk 
mengukur kebahagiaan guru. Namun instrumen iPPQ pula hanya mampu mengukur kebahagiaan guru di tempat kerja sahaja tetapi tidak boleh mengukur kebahagiaan guru merangkumi keseluruhan kehidupan mereka.

Selain itu, terdapat perbezaan yang ketara dalam setiap konstruk yang digunakan dalam iPPQ dan OHI. Konstruk instrumen iPPQ lebih menumpukan kepada nilai diri dan persekitaran guru seperti sumbangan guru, kepercayaan guru, keyakinan guru, penglibatan guru dan iklim sekolah. Tetapi konstruk OHI lebih menumpukan kepada kehidupan guru di tempat kerja seperti kepuasan keseimbangan kerja dengan kehidupan, kepuasan kerja dan kesejahteraan pekerjaan.

Justeru, kajian sorotan literatur bersistematik ini dijalankan untuk mengenal pasti lebih lanjut instrumen-instrumen yang sesuai untuk mengukur kebahagiaan guru di Malaysia. Malah kajian ini turut melakukan saringan terhadap instrumen-instrumen kebahagiaan yang menjadi pilihan para pengkaji kebahagiaan.

\section{Tujuan Dan Objektif Kajian}

Kajian sorotan literatur bersistematik ini bertujuan untuk mengenal pasti instrumen yang mengukur tahap kebahagiaan guru. Objektif kajian ini pula adalah seperti berikut:

i. Mengenal pasti instrumen yang mengukur kebahagiaan.

ii. Mengenal pasti instrumen yang sesuai untuk mengukur tahap kebahagiaan dalam kalangan guru bagi konteks Malaysia.

iii. Mengenal pasti konstruk dalam instrumen pengukuran kebahagiaan guru

\section{Metodologi}

\section{Prosedur Pencarian Literatur}

Strategi pencarian literatur bermula dengan bimbingan objektif kajian. Oleh sebab kajian ini memfokuskan kepada instrumen kebahagiaan, maka kata kunci yang ditentukan berdasarkan tajuk kajian. Kata kunci ini juga di pelbagaikan dengan menggunakan Bahasa Melayu dan Bahasa Inggeris memperluaskan pencarian literatur. Pangkalan data utama yang digunakan dalam pencarian literatur ini ialah Scopus, ERIC, Springer, Research Gate, Dimensions dan Academia.edu manakala pangkalan data sokongan pula ialah Google Scholar. Penggunaan pangkalan data ini akan memudahkan pencarian literatur kerana pangkalan data merupakan suatu tempat pengumpulan data-data literatur bersistematik dan menyeluruh. Rajah 1 menjelaskan dengan lebih lanjut pangkalan data yang digunakan dalam kajian ini.

Rajah 1: Pangkalan Data Pencarian Literatur

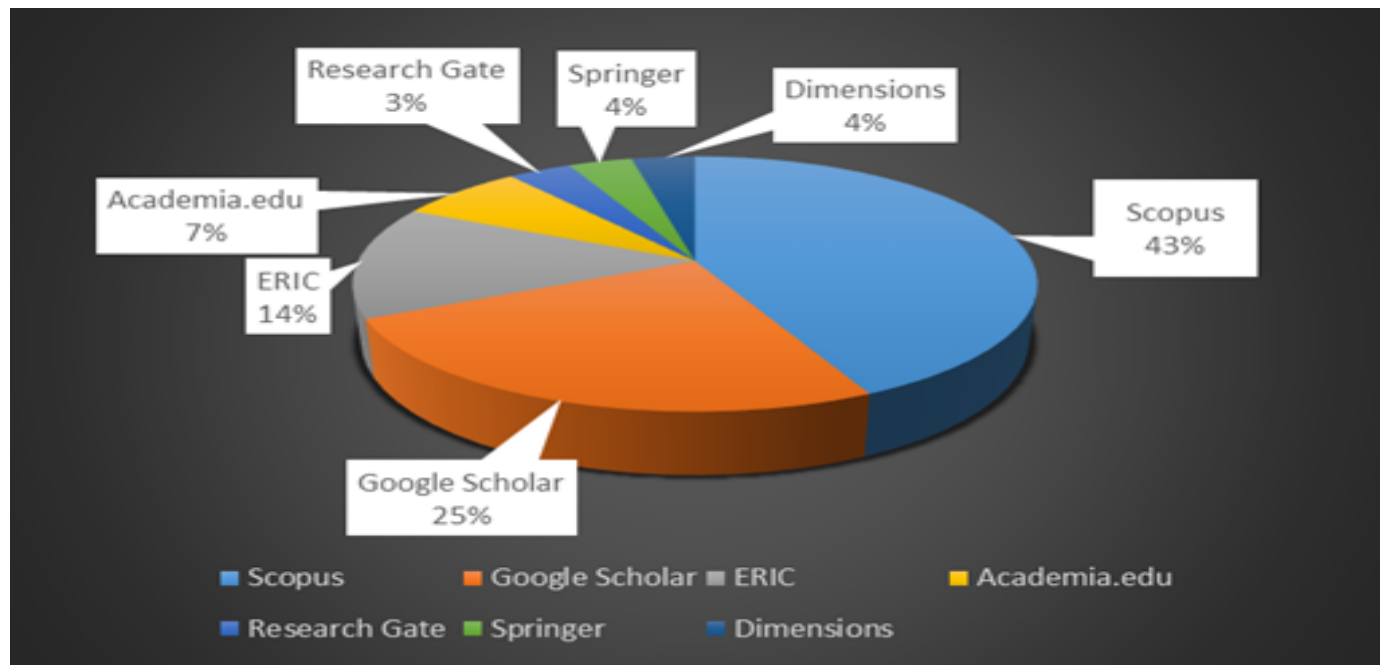


Rajah 1 menunjukkan pangkalan data Scopus (43\%) penyumbang yang terbesar dalam pencarian bahan literatur. Selain itu pangkalan data sokongan iaitu Google Scholar (25\%) antara penyumbang kedua yang tertinggi selepas Scopus. Dalam masa yang sama pangkalan data seperti ERIC (14\%), Academia.edu (7\%), Springer (4\%), Dimensions (4\%) dan Research Gate (3\%) turut memainkan peranan masing-masing dalam menjadi penyumbang kepada pencarian literatur kajian ini.

\section{Kriteria Instrumen}

Kajian tinjauan sama ada kajian tinjauan kritikan ataupun kajian tinjauan kritikal yang melibatkan perbandingan sekumpulan literatur memerlukan penetapan set kriteria mantap (Xiao \& Watson, 2019) dan bersesuaian. Justeru, kajian ini juga menetapkan kriteria yang tertentu bagi memudahkan pencarian literatur. Kriteria penerimaan dan penolakan ditentukan untuk memfokuskan lagi pencarian literatur. Antara kriteria penerimaan yang telah ditetapkan ialah tempoh pencarian literatur telah dihadkan pada Januari 2016 sehinggalah Mei 2020. Garis masa ini ditetapkan untuk membantu mendapatkan literatur kajian baru dan terkini serta garis masa lima tahun sangat sesuai untuk mengelakkan daripada berlakunya kesangsian terhadap dapatan kajian literatur.

Selain itu, literatur kajian ini juga mestilah terdiri daripada artikel jurnal, prosiding dan tesis. Oleh sebab kajian ini lebih menumpukan kepada instrumen yang digunakan, jadi kepelbagaian jenis dokumen literatur diperlukan untuk memudahkan dalam mendapatkan kepelbagaian bahan literatur. Kriteria penerimaan yang terakhir ialah bahasa penghantar. Dalam kajian ini, bahasa penghantar untuk artikel-artikel literatur ialah Bahasa Melayu dan Bahasa Inggeris. Dengan penggunaan kedua-dua bahasa ini sebagai bahasa penghantar akan dapat mengelakkan daripada berlakunya ketidakfahaman. Tambahan pula, Bahasa Inggeris juga merupakan lingua franca (Sifakis, 2017) yang mana lingua franca ialah bahasa pengantaraan antara individu walaupun berbeza bangsa.

Manakala kriteria penolakan pula ialah selain daripada kriteria yang diterima. Jadual 1 di bawah menerangkan secara ringkas kriteria penerimaan dan penolakan. Penentuan kriteria penolakan ini sangat terhad supaya skop pencarian literatur mengenai instrumen kebahagiaan lebih besar dan hal ini akan memudahkan pengkaji untuk mencari persamaan atau perbezaan antara setiap instrumen kebahagiaan yang digunakan.

Jadual 1: Penetapan Kriteria Saringan Instrumen

\begin{tabular}{ccc}
\hline Kriteria Umum & Kriteria Penerimaan & Kriteria Penolakan \\
\hline Tahun penerbitan & Jan 2016 - Mei 2020 & Selain daripada Jan 2016 - \\
& & Mei 2020
\end{tabular}

Jenis Dokumen

Artikel Jurnal, Prosiding dan Tesis

Buku

Bahasa

Bahasa Melayu dan Bahasa

Inggeris

Lain-lain bahasa yang selain

daripada bahasa yang diterima

Di samping proses menetapkan set kriteria, model PRISMA juga digunakan untuk menjadi garis panduan dalam pencarian literatur (Powers, 2017). Dalam Rajah 2 ialah model PRISMA yang digunakan dalam mengenal pasti instrumen kebahagiaan. Proses mengenal pasti instrumen ini dijalankan dengan mencari instrumen yang boleh digunakan untuk mengukur kebahagiaan. Sebanyak 14 buah instrumen telah dikenal pasti sebagai instrumen yang berpotensi untuk mengukur kebahagiaan. Selepas melalui beberapa proses saringan, daripada 14 buah instrumen hanya 10 buah instrumen sahaja yang terpilih menjadi sampel kajian ini. 
Rajah 2: Carta Alir Model PRISMA (Moher et al., 2009)

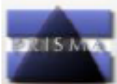

Carta Alir Model PRISMA 2009 (Moher et al. 2009)
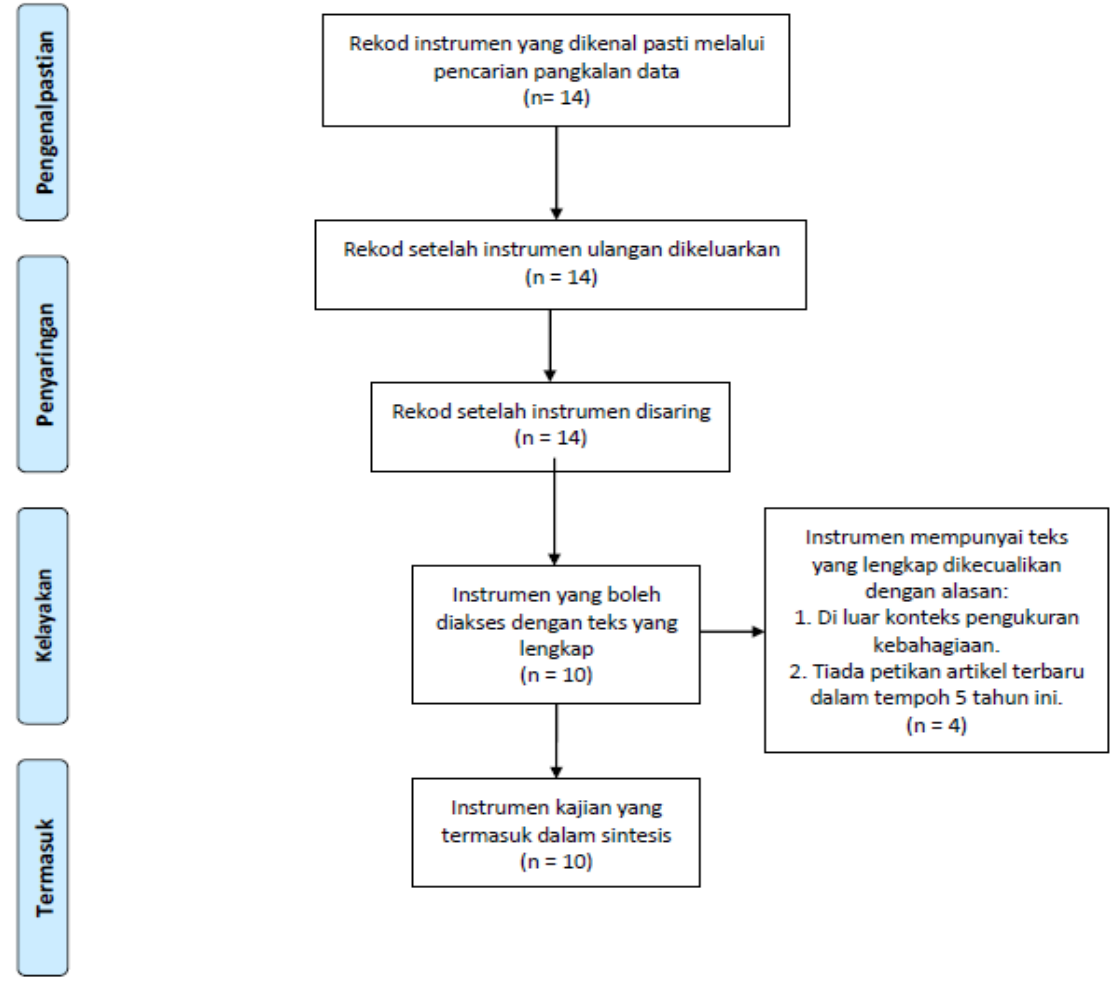

\section{Ekstrak dan Sintesis Data}

Pengekstrakan data dijalankan untuk memudahkan dan merumuskan perbandingan bahan literatur yang memenuhi kriteria yang ditetapkan (Bevan et al., 2020). Data-data instrumen kajian ini telah di saring mengikut kategori yang telah disusun melalui proses pengekstrakan data. Antara kategori yang ditetapkan dalam kajian ini seperti kegunaan instrumen, kekuatan instrumen, kelemahan instrumen, konstruk instrumen dan banyak lain. Kategori-kategori ini juga di sintesis untuk memberi gambaran yang lebih jelas dalam menghasilkan perbandingan yang bermakna (Bevan et al., 2020). Jadi, hasil daripada proses pengekstrakan dan sintesis data ini akan di perjelaskan lebih lanjut dalam bahagian dapatan kajian.

\section{Dapatan Kajian}

\section{Instrumen Saringan}

Hasil daripada analisis yang dijalankan, terdapat sepuluh instrumen yang berjaya dikenal pasti sebagai pengukur kebahagiaan. Antara sepuluh instrumen yang dikenal pasti ialah Aréchiga-Moldovan Happy Scale (AM Happy Scale), Approaches to Happiness, The Authentic Happiness Inventory, Gross Happiness Index, Gross National Happiness Index (GNH Index), Bhutan's Gross National Happiness Index, iopener People Performance Questionnaire (iPPQ), Organizational Happiness Index (OHI), Oxford Happiness Questionnaire dan Subjective Happiness Scale. Jadual 2 menunjukkan secara jelas sepuluh instrumen yang dikenal pasti.

Jadual 2 juga menunjukkan antara kegunaan, kekuatan, kelemahan, jumlah item dan konstruk untuk setiap instrumen. Daripada analisis yang dijalankan oleh pengkaji mendapati bahawa terdapat beberapa 
instrumen dalam kajian ini merupakan versi baru untuk instrumen yang sebelumnya. Antaranya ialah instrumen Approaches to Happiness yang dibangunkan oleh Christopher Peterson (2005) yang merupakan versi baru daripada instrumen The Authentic Happiness Inventory yang dibangunkan oleh Seligman (2002) (Urrutia et al., 2019). Selain itu, Gross Happiness Index dan GNH Index pula merupakan instrumen versi baru daripada instrumen Bhutan's Gross National Happiness Index yang dibangunkan oleh His Majesty the Fourth King of Bhutan, Jigme Singye Wangchuck (2016) (Pratt 2016; Klamár \& Gaval'ová 2018). Instrumen Oxford Happiness Questionnaire juga ialah instrumen versi baru daripada instrumen Oxford Happiness Inventory yang dibangunkan oleh Argyle, Martin, \& Crossland (1989) (Hills \& Argyle, 2002). Oleh disebabkan hal ini, kebanyakan instrumen dalam kajian ini saling berkait rapat antara satu sama lain.

Terdapat beberapa instrumen dalam kajian ini yang digunakan untuk mengukur kebahagiaan di tempat kerja seperti instrumen iPPQ dan OHI antara instrumen yang dibangunkan untuk mengukur kebahagiaan di tempat kerja. Jadi instrumen ini tidak sesuai untuk mengukur kebahagiaan kehidupan individu secara holistik. Terdapat juga beberapa instrumen yang dibangunkan khusus untuk mengukur kebahagiaan kehidupan rakyat di negara tertentu. Contohnya instrumen Bhutan's Gross National Happiness Index yang khusus untuk rakyat negara Bhutan, GNH Index yang khusus untuk rakyat Slovakia dan Gross Happiness Index untuk khusus rakyat Melanesia dan Polynesia. Hal ini kerana instrumen berkenaan dibangunkan khusus mengikut suasana, persekitaran dan gaya hidup rakyat negara berkenaan. Hal ini juga menyebabkan berlakunya pembangunan versi baru instrumen untuk menyesuaikan kandungan instrumen mengikut negara masing-masing. Namun masih lagi terdapat instrumen seperti The Authentic Happiness Inventory, Oxford Happiness Questionnaire dan Subjective Happiness Scale yang boleh diguna pakai tanpa diubah mengikut negara yang ingin dikaji seperti yang ditunjukkan dalam jadual 3.

Di samping itu, kajian ini juga membuat perbandingan instrumen berdasarkan kekuatan dan kelemahan instrumen. Daripada analisis perbandingan yang dijalankan mendapati bahawa instrumen Oxford Happiness Questionnaire antara instrumen yang paling kukuh kekuatannya dan kelemahannya juga tidak menjadi isu yang besar dalam pengukuran kebahagiaan. Instrumen Oxford Happiness Questionnaire mempunyai kelemahannya iaitu skop pengukuran instrumen yang terlalu luas di mana kandungan instrumen lebih mengukur kepada pengalaman individu berbandingan tahap kebahagiaan individu (Kashdan, 2004) tetapi berdasarkan Jadual 3 menunjukkan kebanyakan pengkaji lebih memilih menggunakan instrumen Oxford Happiness Questionnaire daripada instrumen yang lain untuk mengukur kebahagiaan.

Tambahan pula instrumen Oxford Happiness Questionnaire ini sangat sesuai untuk mengukur kebahagiaan kehidupan secara menyeluruh dan instrumen ini mempunyai keunikannya iaitu setiap responden yang menjawab soal selidik instrumen ini akan mendapat skor kebahagiaan kehidupan mereka (Hills \& Argyle, 2002). Hal ini menunjukkan instrumen ini sangat mesra pengguna. Seperkara lagi, instrumen Oxford Happiness Questionnaire ini juga merupakan instrumen yang menggunakan empat pernyataan yang menyerupai dengan pilihan tindak balas dengan Beck Depression Inventory (Medvedev et al., 2016). Walau bagaimanapun, lain-lain instrumen masih lagi sesuai dan mempunyai keunikannya yang tersendiri mengikut keperluan kajian yang ingin dilaksanakan.

\section{Instrumen Mengukur Kebahagiaan Guru}

Analisis perbandingan dalam Jadual 2 dan 3 juga menunjukkan daripada sepuluh instrumen yang terlibat, terdapat lima instrumen yang boleh digunakan dalam mengukur kebahagiaan guru seperti Approaches to Happiness, The Authentic Happiness Inventory, iPPQ, Oxford Happiness Questionnaire dan Subjective Happiness Scale. Hal ini kerana kelima-lima instrumen ini pernah digunakan dalam kajian yang menggunakan guru sebagai sampel kajian.

Lanjutan daripada itu, analisis perbandingan juga mendapati bahawa daripada lima instrumen yang terlibat terdapat satu instrumen iaitu instrumen iPPQ tidak sesuai digunakan dalam mengukur kebahagiaan guru. Hal ini kerana instrumen ini hanya mengukur kebahagiaan di tempat kerja (Jones, 2010) sahaja bukannya mengukur kebahagiaan secara menyeluruh. Oleh kerana itu, hanya terdapat 
empat instrumen yang sesuai untuk mengukur kebahagiaan guru iaitu Approaches to Happiness, The Authentic Happiness Inventory, Oxford Happiness Questionnaire dan Subjective Happiness Scale.

\section{Konstruk Instrumen}

Setiap sepuluh buah instrumen dalam kajian ini mempunyai kepelbagaian jumlah dan bilangan konstruk. Antaranya ialah instrumen AM Happy Scale dan Subjective Happiness Scale merupakan instrumen yang tidak mempunyai konstruk. Jumlah item untuk instrumen AM Happy Scale sebanyak satu item manakala instrumen Subjective Happiness Scale mempunyai empat item. Jumlah item yang agak sedikit ini menyumbang kepada ketiadaan konstruk untuk instrumen berkenaan. Instrumen Oxford Happiness Questionnaire juga tidak mempunyai konstruk dalam instrumen namun setiap item instrumen telah dibahagikan kepada dua bahagian iaitu item positif sebanyak 18 item dan item negatif sebanyak 11 item. Hal ini menunjukkan bahawa ketiadaan konstruk ini bergantung kepada pengkaji yang membina instrumen terlibat.

Manakala instrumen seperti Approaches to Happiness dan The Authentic Happiness Inventory yang menyokong kepada teori kebahagiaan autentik mempunyai tiga konstruk utama. Ketiga-tiga konstruk ini merupakan elemen asas dalam teori kebahagiaan autentik iaitu kehidupan yang menyenangkan, kehidupan yang baik dan kehidupan yang bermakna. Tetapi yang membezakan instrumen Approaches to Happiness dan The Authentic Happiness Inventory ialah jumlah item untuk setiap instrumen.

Selain itu terdapat instrumen lain yang mempunyai 3 konstruk iaitu instrumen OHI. Instrumen ini menggunakan teori kebahagiaan autentik dalam pembina instrumen (Omar et al., 2016). Perbezaan instrumen ini dengan instrumen Approaches to Happiness dan The Authentic Happiness Inventory ialah elemen konstruk yang berbeza sudut pengukurannya. Instrumen OHI ini menggunakan elemen konstruk seperti kepuasan keseimbangan kerja dengan kehidupan, kepuasan kerja dan kesejahteraan pekerja. Instrumen ini juga memfokuskan pengukuran kebahagiaan di tempat kerja. Instrumen iPPQ pula memandang kebahagiaan daripada sesi tempat kerja. Instrumen iPPQ ini mempunyai 5 konstruk iaitu sumbangan guru, kepercayaan guru, iklim sekolah, penglibatan guru dan keyakinan guru. Konstruk yang digunakan ini juga agak berbeza dengan konstruk instrumen-instrumen lain.

Seterusnya terdapat tiga instrumen yang mempunyai konstruk yang sama. Instrumennya ialah instrumen Gross Happiness Index, GNH Index dan Bhutan's Gross National Happiness Index yang mempunyai 9 konstruk dalam instrumen. Selain daripada mempunyai jumlah konstruk instrumen yang paling banyak, instrumen-instrumen ini juga merupakan antara instrumen yang mempunyai jumlah item yang banyak. Instrumen Gross Happiness Index dan Bhutan's Gross National Happiness Index mempunyai jumlah item sebanyak 135 item manakala GNH Index mempunyai 52 item. Walaupun instrumen Gross Happiness Index dan Bhutan's Gross National Happiness Index memiliki jumlah item dan konstruk yang sama tetapi terdapat perbezaan dalam subkonstruk instrumen berkenaan. Ketiga-tiga instrumen ini mempunyai perbezaannya yang tersendiri kerana keperluan item disemak mengikut penyesuaian rakyat di negara yang berkaitan.

Mengikut persamaan dan perbezaan yang wujud dalam setiap instrumen dapat disimpulkan bahawa antara konstruk yang paling banyak yang digunakan ialah psikologi. Psikologi dalam konteks kajian ini merujuk kepada perasaan bahagia, keyakinan, kepuasan dan tanggapan individu. Setiap sepuluh instrumen kajian mempunyai elemen psikologi dalam item soal selidik. Oleh sebab kebahagiaan juga berkaitan rapat dengan psikologi jadi kebanyakan soal selidik kebahagiaan akan melibatkan soalansoalan psikologi. Justeru konstruk psikologi antara konstruk yang sesuai dan paling banyak digunakan dalam instrumen kebahagiaan. 
Jadual 2: Senarai Instrumen Berdasarkan Kegunaan, Kekuatan, Kelemahan dan Konstruk

\begin{tabular}{|c|c|c|c|c|c|c|}
\hline $\begin{array}{c}\text { Nama } \\
\text { Instrumen }\end{array}$ & Pengasas & Kegunaan & Kekuatan & Kelemahan & $\begin{array}{c}\text { Jumlah } \\
\text { Item }\end{array}$ & $\begin{array}{c}\text { Konstruk } \\
\text { Instrumen }\end{array}$ \\
\hline $\begin{array}{l}\text { Aréchiga- } \\
\text { Moldovan } \\
\text { Happy Scale } \\
\text { (AM Happy } \\
\text { Scale) }\end{array}$ & $\begin{array}{l}\text { Hadley } \\
\text { Cantril } \\
(1965)\end{array}$ & $\begin{array}{l}\text { Skala } \\
\text { pengukuran } \\
\text { yang } \\
\text { mengukur } \\
\text { tahap } \\
\text { kebahagiaan } \\
\text { individu } \\
\text { dewasa di } \\
\text { Amerika } \\
\text { Syarikat }\end{array}$ & $\begin{array}{l}\text { Pengukuran yang } \\
\text { ringkas, tidak } \\
\text { mengambil masa } \\
\text { lama dan } \\
\text { responden tidak } \\
\text { berasa bosan, letih } \\
\text { dan kecewa } \\
\text { dengan bilangan } \\
\text { item soalan yang } \\
\text { banyak. Skala ini } \\
\text { juga lebih mesra } \\
\text { pengguna. }\end{array}$ & $\begin{array}{l}\text { Skala pengukuran } \\
\text { ialah skala pengukuran } \\
\text { item tunggal ataupun } \\
\text { single-item rating } \\
\text { scales. Terdapat } \\
\text { kesangsian dalam } \\
\text { skala pengukuran item } \\
\text { tunggal dalam } \\
\text { mengukur } \\
\text { kebahagiaan secara } \\
\text { berkesan. Tidak } \\
\text { banyak artikel kajian } \\
\text { lain yang } \\
\text { menggunakan } \\
\text { instrumen ini. }\end{array}$ & $\begin{array}{l}\text { Jumlah } \\
\text { item: } 1 \\
\text { (Tahap } \\
\text { Kebahagia } \\
\text { an } \\
\text { Semasa) }\end{array}$ & $\begin{array}{l}\text { Tiada konstruk } \\
\text { dalam instrumen. }\end{array}$ \\
\hline $\begin{array}{l}\text { Approaches } \\
\text { to } \\
\text { Happiness }\end{array}$ & $\begin{array}{l}\text { Christoph } \\
\text { er } \\
\text { Peterson } \\
(2005)\end{array}$ & $\begin{array}{l}\text { Digunakan } \\
\text { untuk } \\
\text { mengukur } \\
\text { kebahagiaan } \\
\text { daripada } \\
\text { segi } \\
\text { kehidupan } \\
\text { yang } \\
\text { menyenangk } \\
\text { an, } \\
\text { kehidupan } \\
\text { yang baik } \\
\text { dan } \\
\text { kehidupan } \\
\text { yang } \\
\text { bermakna. }\end{array}$ & $\begin{array}{l}\text { Instrumen ini } \\
\text { mendukung teori } \\
\text { kebahagiaan } \\
\text { autentik oleh } \\
\text { Seligman. Graf } \\
\text { instrumen ini } \\
\text { bertaburan normal } \\
\text { dan kurang } \\
\text { condong ( } \text { (kewed). } \\
\text { Instrumen ini juga } \\
\text { lebih sensitif } \\
\text { terhadap } \\
\text { perubahan dalam } \\
\text { aspek } \\
\text { kebahagiaan. }\end{array}$ & $\begin{array}{l}\text { Instrumen ini boleh } \\
\text { diakses dalam talian } \\
\text { sahaja dan terdapat } \\
\text { kesukaran dalam } \\
\text { mendapatkan dan } \\
\text { mengakses instrumen } \\
\text { yang lengkap. }\end{array}$ & $\begin{array}{l}\text { Jumlah } \\
\text { Item: } 21\end{array}$ & $\begin{array}{l}\text { Terdapat } 3 \\
\text { konstruk: } \\
\text { 1. Kehidupan } \\
\text { yang } \\
\text { menyenangkan } \\
\text { 2. Kehidupan } \\
\text { yang baik } \\
\text { 3. Kehidupan } \\
\text { yang bermakna }\end{array}$ \\
\hline $\begin{array}{l}\text { The } \\
\text { Authentic } \\
\text { Happiness } \\
\text { Inventory }\end{array}$ & $\begin{array}{l}\text { Seligman } \\
(2002)\end{array}$ & $\begin{array}{l}\text { Digunakan } \\
\text { untuk } \\
\text { mengukur } \\
\text { kebahagiaan } \\
\text { daripada } \\
\text { segi aspek } \\
\text { hubungan } \\
\text { interpersona } \\
\text { 1, kehidupan } \\
\text { yang } \\
\text { bermakna } \\
\text { dan } \\
\text { bertujuan, } \\
\text { kehidupan } \\
\text { yang } \\
\text { menyenangk } \\
\text { an dengan } \\
\text { emosi yang } \\
\text { positif dan } \\
\text { penglibatan } \\
\text { dalam } \\
\text { kehidupan. }\end{array}$ & $\begin{array}{l}\text { Instrumen ini } \\
\text { mendukung teori } \\
\text { kebahagiaan } \\
\text { autentik oleh } \\
\text { Seligman. Graf } \\
\text { instrumen ini } \\
\text { bertaburan normal } \\
\text { dan kurang } \\
\text { condong (skewed). } \\
\text { Instrumen ini juga } \\
\text { lebih sensitif } \\
\text { terhadap } \\
\text { perubahan dalam } \\
\text { aspek } \\
\text { kebahagiaan. }\end{array}$ & $\begin{array}{l}\text { Instrumen ini boleh } \\
\text { diakses dalam talian } \\
\text { sahaja dan terdapat } \\
\text { kesukaran dalam } \\
\text { mendapatkan dan } \\
\text { mengakses instrumen } \\
\text { yang lengkap. }\end{array}$ & $\begin{array}{l}\text { Jumlah } \\
\text { Item: } 20\end{array}$ & $\begin{array}{l}\text { Terdapat } 3 \\
\text { konstruk: } \\
\text { 1. Kehidupan } \\
\text { yang } \\
\text { menyenangkan } \\
\text { 2. Kehidupan } \\
\text { yang baik } \\
\text { 3. Kehidupan } \\
\text { yang bermakna }\end{array}$ \\
\hline $\begin{array}{l}\text { Gross } \\
\text { Happiness } \\
\text { Index }\end{array}$ & $\begin{array}{l}\text { Stephen } \\
\text { Pratt } \\
(2016)\end{array}$ & $\begin{array}{l}\text { Digunakan } \\
\text { untuk } \\
\text { mengukur } \\
\text { kebahagiaan } \\
\text { individu di } \\
\text { Pulau } \\
\text { Solomon, } \\
\text { Melanesia } \\
\text { dan Tonga, } \\
\text { Polynesia }\end{array}$ & $\begin{array}{l}\text { Instrumen ini } \\
\text { mampu mengukur } \\
\text { kebahagiaan } \\
\text { masyarakat secara } \\
\text { holistik }\end{array}$ & $\begin{array}{l}\text { Jumlah item yang } \\
\text { banyak. Setiap } \\
\text { konstruk bersifat } \\
\text { subjektif dan } \\
\text { dilaporkan sendiri oleh } \\
\text { responden }\end{array}$ & $\begin{array}{l}\text { Jumlah } \\
\text { Item: } 135\end{array}$ & $\begin{array}{l}\text { Terdapat } 9 \\
\text { konstruk: } \\
\text { 1. Psikologi } \\
\text { 2. Kesihatan } \\
\text { 3. Penggunaan } \\
\text { Masa } \\
\text { 4. Pendidikan } \\
\text { 5. Kepelbagaian } \\
\text { Budaya } \\
\text { 6. Kerajaan } \\
\text { 7. Vatiliti Sosial }\end{array}$ \\
\hline
\end{tabular}




\begin{tabular}{|c|c|c|c|c|c|c|}
\hline $\begin{array}{l}\text { Gross } \\
\text { National } \\
\text { Happiness } \\
\text { Index (GNH } \\
\text { Index) }\end{array}$ & $\begin{array}{l}\text { Radoslav } \\
\text { Klamár \& } \\
\text { Anna } \\
\text { Gaval'ová } \\
(2018)\end{array}$ & $\begin{array}{l}\text { Digunakan } \\
\text { untuk } \\
\text { mengukur } \\
\text { kebahagiaan } \\
\text { individu di } \\
\text { Slovakia }\end{array}$ & $\begin{array}{l}\text { Instrumen ini } \\
\text { mampu mengukur } \\
\text { kebahagiaan } \\
\text { masyarakat secara } \\
\text { holistik }\end{array}$ & $\begin{array}{l}\text { Terdapat kesukaran } \\
\text { dalam mendapatkan } \\
\text { dan mengakses } \\
\text { instrumen yang } \\
\text { lengkap. }\end{array}$ & $\begin{array}{l}\text { Jumlah } \\
\text { Item: } 52\end{array}$ & $\begin{array}{l}\text { 9. Taraf Hidup } \\
\text { Terdapat } 9 \\
\text { konstruk: } \\
\text { 1. Psikologi } \\
\text { 2. Kesihatan } \\
\text { 3. Penggunaan } \\
\text { Masa } \\
\text { 4. Pendidikan } \\
\text { 5. Kepelbagaian } \\
\text { Budaya } \\
\text { 6. Kerajaan } \\
\text { 7. Vatiliti Sosial } \\
\text { 8. Kepelbagaian } \\
\text { Ekologi } \\
\text { 9. Taraf Hidup }\end{array}$ \\
\hline $\begin{array}{l}\text { Bhutan's } \\
\text { Gross } \\
\text { National } \\
\text { Happiness } \\
\text { Index }\end{array}$ & $\begin{array}{l}\text { His } \\
\text { Majesty } \\
\text { the } \\
\text { Fourth } \\
\text { King of } \\
\text { Bhutan, } \\
\text { Jigme } \\
\text { Singye } \\
\text { Wangchu } \\
\text { ck(2016) }\end{array}$ & $\begin{array}{l}\text { Digunakan } \\
\text { untuk } \\
\text { mengukur } \\
\text { kebahagiaan } \\
\text { masyarakat } \\
\text { di Bhutan }\end{array}$ & $\begin{array}{l}\text { Instrumen ini } \\
\text { mampu mengukur } \\
\text { kebahagiaan } \\
\text { masyarakat secara } \\
\text { holistik }\end{array}$ & $\begin{array}{l}\text { Jumlah item yang } \\
\text { banyak. }\end{array}$ & $\begin{array}{l}\text { Jumlah } \\
\text { Item: } 135\end{array}$ & $\begin{array}{l}\text { Terdapat } 9 \\
\text { konstruk: } \\
\text { 1. Psikologi } \\
\text { 2. Kesihatan } \\
\text { 3. Penggunaan } \\
\text { Masa } \\
\text { 4. Pendidikan } \\
\text { 5. Kepelbagaian } \\
\text { Budaya } \\
\text { 6. Kerajaan } \\
\text { 7. Vatiliti Sosial } \\
\text { 8. Kepelbagaian } \\
\text { Ekologi } \\
\text { 9. Taraf Hidup }\end{array}$ \\
\hline $\begin{array}{l}\text { iopener } \\
\text { People } \\
\text { Performance } \\
\text { Questionnai } \\
\text { re (iPPQ) }\end{array}$ & $\begin{array}{l}\text { Pryce- } \\
\text { Jones } \\
(2010)\end{array}$ & $\begin{array}{l}\text { Digunakan } \\
\text { untuk } \\
\text { mengukur } \\
\text { kebahagiaan } \\
\text { di tempat } \\
\text { kerja }\end{array}$ & $\begin{array}{l}\text { Kebanyakan } \\
\text { pengkaji daripada } \\
\text { Malaysia } \\
\text { menggunakan } \\
\text { instrumen ini } \\
\text { untuk mengukur } \\
\text { kebahagiaan di } \\
\text { tempat kerja. } \\
\text { Kebanyakan } \\
\text { kajian juga } \\
\text { menggunakan } \\
\text { instrumen ini } \\
\text { untuk mengukur } \\
\text { kebahagiaan guru } \\
\text { di tempat kerja. }\end{array}$ & $\begin{array}{l}\text { Instrumen ini } \\
\text { memfokuskan kepada } \\
\text { kebahagiaan di tempat } \\
\text { kerja sahaja dan } \\
\text { bukannya instrumen } \\
\text { kebahagiaan } \\
\text { kehidupan secara } \\
\text { menyeluruh. }\end{array}$ & $\begin{array}{l}\text { Jumlah } \\
\text { item: } 20\end{array}$ & $\begin{array}{l}\text { Terdapat } 5 \\
\text { konstruk: } \\
\text { 1. Sumbangan } \\
\text { guru } \\
\text { 2. Kepercayaan } \\
\text { guru } \\
\text { 3. Iklim sekolah } \\
\text { 4. Penglibatan } \\
\text { guru } \\
\text { 5. Keyakinan guru }\end{array}$ \\
\hline $\begin{array}{l}\text { Organizatio } \\
\text { nal } \\
\text { Happiness } \\
\text { Index (OHI) }\end{array}$ & $\begin{array}{l}\text { Muhamad } \\
\text { Khalil } \\
\text { Omar, } \\
\text { Ridhawati } \\
\text { Zakaria \& } \\
\text { Azzarina } \\
\text { Zakaria } \\
(2016)\end{array}$ & $\begin{array}{l}\text { Digunakan } \\
\text { untuk } \\
\text { mengukur } \\
\text { kebahagiaan } \\
\text { di sesebuah } \\
\text { organisasi }\end{array}$ & $\begin{array}{l}\text { Instrumen in } \\
\text { dikonsepkan } \\
\text { menggunakan } \\
\text { teori kebahagiaan } \\
\text { autentik oleh } \\
\text { Seligman }\end{array}$ & $\begin{array}{l}\text { Instrumen ini } \\
\text { memfokuskan kepada } \\
\text { kebahagiaan di tempat } \\
\text { kerja sahaja dan } \\
\text { bukannya instrumen } \\
\text { kebahagiaan } \\
\text { kehidupan secara } \\
\text { menyeluruh. }\end{array}$ & $\begin{array}{l}\text { Jumlah } \\
\text { Item: } 72\end{array}$ & $\begin{array}{l}\text { Terdapat } 3 \\
\text { konstruk: } \\
\text { 1. Kepuasan } \\
\text { keseimbangan } \\
\text { kerja dengan } \\
\text { kehidupan } \\
\text { 2. Kepuasan kerja } \\
\text { 3. Kesejahteraan } \\
\text { pekerja }\end{array}$ \\
\hline $\begin{array}{l}\text { Oxford } \\
\text { Happiness } \\
\text { Questionnai } \\
\text { re }\end{array}$ & $\begin{array}{l}\text { Hills and } \\
\text { Argyle } \\
(2002)\end{array}$ & $\begin{array}{l}\text { Digunakan } \\
\text { untuk } \\
\text { mengukur } \\
\text { kebahagiaan } \\
\text { individu }\end{array}$ & $\begin{array}{l}\text { Kebanyakan } \\
\text { pengkaji } \\
\text { menggunakan } \\
\text { instrumen ini } \\
\text { untuk mengukur } \\
\text { kebahagiaan } \\
\text { dalam kajian } \\
\text { mereka. }\end{array}$ & $\begin{array}{l}\text { Instrumen ini dikritik } \\
\text { kerana terlalu besar } \\
\text { skop kebahagiaan } \\
\text { yang dikaji. }\end{array}$ & $\begin{array}{l}\text { Jumlah } \\
\text { item: } 29\end{array}$ & $\begin{array}{l}\text { Tiada konstruk } \\
\text { tetapi terdapat } 2 \\
\text { pembahagian item } \\
\text { iaitu: } \\
\text { 1. Positif item } \\
\text { 2. Negatif item }\end{array}$ \\
\hline
\end{tabular}



DOI: https://doi.org/10.47405/mjssh.v5i10.514

\begin{tabular}{|c|c|c|c|c|c|c|}
\hline $\begin{array}{l}\text { Subjective } \\
\text { Happiness } \\
\text { Scale }\end{array}$ & $\begin{array}{l}\text { Lyubomir } \\
\text { sky \& } \\
\text { Lepper } \\
(1999)\end{array}$ & $\begin{array}{l}\text { Digunakan } \\
\text { untuk } \\
\text { mengukur } \\
\text { kebahagiaan } \\
\text { subjektif }\end{array}$ & $\begin{array}{l}\text { Instrumen ini } \\
\text { ringkas dan tidak } \\
\text { akan membuat } \\
\text { responden } \\
\text { terbeban dan } \\
\text { bosan dengan } \\
\text { kuantiti item yang } \\
\text { banyak. }\end{array}$ & $\begin{array}{l}\text { Tidak mengukur } \\
\text { kebahagiaan secara } \\
\text { menyeluruh dan } \\
\text { terperinci. }\end{array}$ & $\begin{array}{l}\text { Jumlah } \\
\text { item: } 4\end{array}$ & $\begin{array}{l}\text { Tiada konstruk } \\
\text { dalam instrumen } \\
\text { tetapi terdapat } 4 \\
\text { item: } \\
\text { 1) Tahap } \\
\text { kebahagiaan } \\
\text { secara general } \\
\text { 2) Perbandingan } \\
\text { kebahagiaan } \\
\text { dengan rakan } \\
\text { sebaya } \\
\text { 3) Pendapat } \\
\text { tentang gambaran } \\
\text { orang yang } \\
\text { bahagia } \\
\text { 4) Pendapat } \\
\text { gambaran orang } \\
\text { yang tidak } \\
\text { bahagia }\end{array}$ \\
\hline
\end{tabular}

Jadual 3: Senarai Instrumen Berdasarkan Rujukan dan Konteks

\begin{tabular}{|c|c|c|c|c|}
\hline Nama Instrumen & Pengasas & Petikan Artikel & $\begin{array}{c}\text { Negara Petikan } \\
\text { Artikel }\end{array}$ & $\begin{array}{l}\text { Sampel } \\
\text { Kajian } \\
\text { Petikan } \\
\text { Artikel } \\
\end{array}$ \\
\hline $\begin{array}{l}\text { Aréchiga-Moldovan Happy } \\
\text { Scale (AM Happy Scale) }\end{array}$ & $\begin{array}{l}\text { Hadley Cantril } \\
\text { (1965) }\end{array}$ & Moldovan (2017) & California & Bukan guru \\
\hline Approaches to Happiness & $\begin{array}{c}\text { Christopher } \\
\text { Peterson (2005) }\end{array}$ & Urrutia et al. (2019) & Filipina & Guru \\
\hline $\begin{array}{l}\text { The Authentic Happiness } \\
\text { Inventory }\end{array}$ & Seligman (2002) & $\begin{array}{l}\text { Proyer et al. (2016) } \\
\text { Clemons (2018) } \\
\text { Proyer \& Gander (2018) } \\
\text { Sanli et al. (2019) }\end{array}$ & $\begin{array}{l}\text { Switzerland } \\
\text { Amerika } \\
\text { Syarikat } \\
\text { Switzerland } \\
\text { Turki }\end{array}$ & $\begin{array}{l}\text { Bukan guru } \\
\text { Guru } \\
\text { Bukan guru } \\
\text { Bukan guru }\end{array}$ \\
\hline Gross Happiness Index & $\begin{array}{l}\text { Stephen Pratt } \\
\text { (2016) }\end{array}$ & Pratt (2016) & $\begin{array}{l}\text { Kepulauan } \\
\text { Solomon dan } \\
\text { Tongan }\end{array}$ & Bukan guru \\
\hline $\begin{array}{l}\text { Gross National Happiness } \\
\text { Index (GNH Index) }\end{array}$ & $\begin{array}{l}\text { Radoslav Klamár } \\
\text { \& Anna Gaval'ová } \\
\text { (2018) }\end{array}$ & Klamár \& Gaval’ová (2018) & Slovakia & Bukan guru \\
\hline $\begin{array}{l}\text { Bhutan's Gross National } \\
\text { Happiness Index }\end{array}$ & $\begin{array}{l}\text { His Majesty the } \\
\text { Fourth King of } \\
\text { Bhutan, Jigme } \\
\text { Singye } \\
\text { Wangchuck } \\
\text { (2016) }\end{array}$ & $\begin{array}{l}\text { Centre for Bhutan Studies \& } \\
\text { GNH Research (2016) }\end{array}$ & Bhutan & Bukan guru \\
\hline $\begin{array}{l}\text { iopener People Performance } \\
\text { Questionnaire (iPPQ) }\end{array}$ & $\begin{array}{l}\text { Pryce-Jones } \\
\quad(2010)\end{array}$ & $\begin{array}{c}\text { Abdullah et al. (2016) } \\
\text { Abdullah \& Ling (2016a) } \\
\text { Abdullah \& Ling (2016b) } \\
\text { Abdullah, Ling \& Ping (2016) }\end{array}$ & Malaysia & Guru \\
\hline $\begin{array}{l}\text { Organizational Happiness } \\
\text { Index }(\mathrm{OHI})\end{array}$ & $\begin{array}{l}\text { Muhamad Khalil } \\
\text { Omar, Ridhawati } \\
\text { Zakaria \& } \\
\text { Azzarina Zakaria } \\
\text { (2016) }\end{array}$ & $\begin{array}{l}\text { Omar et al. (2016) } \\
\text { Omar et al. (2018) }\end{array}$ & Malaysia & Bukan guru \\
\hline $\begin{array}{l}\text { Oxford Happiness } \\
\text { Questionnaire }\end{array}$ & $\begin{array}{l}\text { Hills and Argyle } \\
\text { (2002) }\end{array}$ & $\begin{array}{c}\text { Jalali \& Heidari (2016) } \\
\text { Medvedev et al. (2016) } \\
\text { İhtiyaroğlu (2018) } \\
\text { Mertoğlu (2018) } \\
\text { Kamthan et al. (2019) } \\
\text { Çakır \& Harmandar Demirel } \\
\text { (2019) } \\
\text { Kim et al. (2019) }\end{array}$ & $\begin{array}{c}\text { Iran } \\
\text { New Zealand } \\
\text { Turki } \\
\text { Turki } \\
\text { India } \\
\text { Turki } \\
\text { Korea } \\
\text { Turki }\end{array}$ & $\begin{array}{l}\text { Guru } \\
\text { Bukan guru } \\
\text { Guru } \\
\text { Guru } \\
\text { Bukan guru } \\
\text { Guru } \\
\text { Bukan guru } \\
\text { Bukan guru }\end{array}$ \\
\hline
\end{tabular}



DOI: https://doi.org/10.47405/mjssh.v5i10.514

\begin{tabular}{|c|c|c|c|c|}
\hline & & $\begin{array}{c}\text { Baltaci (2019) } \\
\text { Taghvaienia \& Alamdari } \\
(2019) \\
\text { Ardiati (2019) } \\
\text { Panda \& Sinha (2020) }\end{array}$ & $\begin{array}{l}\text { Iran } \\
\text { Indonesia } \\
\text { India }\end{array}$ & $\begin{array}{l}\text { Guru } \\
\text { Guru } \\
\text { Guru }\end{array}$ \\
\hline Subjective Happiness Scale & $\begin{array}{l}\text { Lyubomirsky \& } \\
\text { Lepper (1999) }\end{array}$ & $\begin{array}{c}\text { Turner et al. (2016) } \\
\text { Benevene et al. (2019) } \\
\text { Uğur et al. (2019) }\end{array}$ & $\begin{array}{l}\text { Australia } \\
\text { Sepanyol } \\
\text { Turki } \\
\end{array}$ & $\begin{array}{c}\text { Bukan guru } \\
\text { Guru } \\
\text { Guru }\end{array}$ \\
\hline
\end{tabular}

\section{Perbincangan}

Kebanyakan instrumen yang dikaji dalam kajian ini menggunakan sampel kajian dari luar negara seperti Turki, New Zealand, Korea, Amerika Syarikat dan banyak lagi. Walaupun begitu, terdapat juga instrumen seperti iPPQ dan OHI yang menggunakan rakyat Malaysia sebagai sampel kajian. Tetapi terdapat beberapa isu yang berbangkit melibatkan kedua instrumen ini. Pertama instrumen iPPQ dan OHI merupakan instrumen yang mengukur kebahagiaan di tempat kerja sahaja dan tidak mengukur kebahagiaan secara menyeluruh. Kedua, instrumen iPPQ dan OHI tidak pernah diuji ke atas guru sebagai sampel kajian. Hal ini sedikit sebanyak menimbulkan isu yang berbangkit. Jadi dengan kajian sorotan literatur bersistematik tentang pengukuran kebahagiaan guru ini dapat membantu dalam membuat perbandingan dan pemilihan instrumen yang sesuai untuk digunakan ke atas guru di Malaysia.

Berdasarkan analisis kajian ini dan pemerhatian jadual 2 dan 3, penulis berpendapat bahawa instrumen yang paling sesuai dalam pengukuran kebahagiaan guru ialah instrumen Oxford Happiness Questionnaire. Walaupun hanya terdapat kajian dari luar negara sahaja yang menggunakan instrumen ini untuk mengukur kebahagiaan guru, namun terdapat beberapa justifikasi yang melayakkan instrumen ini digunakan dalam kajian kebahagiaan guru di Malaysia.

Pertama sekali instrumen Oxford Happiness Questionnaire mudah untuk diakses oleh mana-mana pengkaji. Kemudahan untuk mengakses instrumen ini secara lengkap sedikit sebanyak memudahkan pengkaji dalam melaksanakan penyelidikan mereka. Instrumen ini bukan sahaja boleh diakses oleh pengkaji luar negara malahan pengkaji dalam negara Malaysia juga. Tambahan pula instrumen ini juga dapat diakses secara percuma tanpa sebarang bayaran yang dikenakan. Hal ini bukan sahaja dapat menjimatkan masa pengkaji malahan dapat menjimatkan kos untuk pengkaji dalam melakukan penyelidikan.

Kedua, instrumen ini sangat popular dalam kalangan pengkaji dalam mengukur kebahagiaan guru. Kajian yang dilaksanakan oleh Jalali \& Heidari (2016), Zhang et al. (2016), İhtiyaroğlu (2018), Mertoğlu (2018), Çakır \& Harmandar Demirel (2019), Taghvaienia \& Alamdari (2019), Ardiati (2019) dan Panda \& Sinha (2020) merupakan antara kajian yang menggunakan instrumen Oxford Happiness Questionnaire sebagai pengukur kebahagiaan guru. Ini jelas menunjukkan bahawa instrumen ini mendapat tempat dalam kalangan pengkaji.

Ketiga, rata-rata artikel kajian yang menggunakan instrumen Oxford Happiness Questionnaire ialah artikel dari pangkalan data Scopus. Jadual 4 di bawah menunjukkan pangkalan data petikan artikel yang menggunakan instrumen Oxford Happiness Questionnaire.

Jadual 4: Pangkalan Data Petikan Artikel Instrumen Oxford Happiness Questionnaire

\begin{tabular}{cll}
\hline Bil & Petikan Artikel & Pangkalan Data \\
\hline 1 & Jalali \& Heidari (2016) & ERIC \\
2 & Medvedev et al. (2016) & Scopus \\
3 & İhtiyaroğlu (2018) & Scopus \\
4 & Mertoğlu (2018) & ERIC \\
5 & Kamthan et al. (2019) & Scopus \\
\hline
\end{tabular}



DOI: https://doi.org/10.47405/mjssh.v5i10.514

\begin{tabular}{cll}
\hline 6 & Çakır \& Harmandar Demirel (2019) & ERIC \\
7 & Kim et al. (2019) & Scopus \\
8 & Baltacı (2019) & ERIC \\
9 & Taghvaienia \& Alamdari (2019) & Scopus \\
10 & Ardiati (2019) & Google Scholar \\
11 & Panda \& Sinha (2020) & Google Scholar \\
\hline
\end{tabular}

Berdasarkan Jadual 4 yang ditunjukkan, jelas membuktikan bahawa kebanyakan petikan artikel kajian ini adalah artikel Scopus. Pangkalan data Scopus ialah satu kumpulan data yang mementingkan kualiti artikel dan pangkalan data Scopus juga merupakan gambaran yang menyeluruh tentang dapatan penyelidikan saintifik dunia dari semua sudut bidang ilmu (Elsevier, 2013). Jadi artikel kajian tergolong dalam data pangkalan data Scopus jelas menunjukkan bahawa artikel berkenaan mempunyai kualiti dalam penyelidikannya.

Yang terakhirnya ialah kesesuaian instrumen Oxford Happiness Questionnaire dalam mengukur kebahagiaan guru di Malaysia. Kesesuaian dalam konteks kajian ini merujuk kepada keupayaan instrumen ini dalam menyesuaikan setiap elemen dalam setiap konstruk instrumen untuk digunakan dalam mengukur kebahagiaan guru di Malaysia. Kesesuaian ini juga dapat dilihat melalui ujian kebolehpercayaan instrumen. Mengikut kajian Hills \& Argyle (2002) membuktikan bahawa kebolehpercayaan ketekalan dalaman instrumen ini mencapai 0.85. Selepas 6 bulan pengujian semula kebolehpercayaan instrumen ialah 0.67 dan selepas 6 tahun daripada tempoh instrumen dibina pengujian semula kebolehpercayaan instrumen mencatatkan antara 0.5 sehingga 0.6 (Zhang et al., 2016).

Justeru dengan kesemua justifikasi yang dinyatakan jelas menggambarkan potensi instrumen Oxford Happiness Questionnaire untuk digunakan dalam pengukuran kebahagiaan guru di Malaysia. Namun instrumen ini masih lagi boleh digunakan dalam pengukuran kebahagiaan individu bukan guru. Hal ini kerana instrumen ini bersifat universal dan mempunyai kebolehsesuaian yang tinggi.

\section{Kesimpulan}

Dapatan menunjukkan bahawa terdapat empat instrumen yang sesuai bagi mengukur kebahagiaan guru. Penemuan ini memudahkan para pengkaji akan datang untuk mengenal pasti instrumen yang sesuai untuk mengukur kebahagiaan mengikut konteks kajian masing-masing. Instrumen yang dilaporkan menerusi teknik SLR ini didapati mempunyai kegunaan, kekuatan dan kelemahannya yang tersendiri. Oleh itu, maklumat penyelarasan ini sangat diperlukan untuk memenuhi keperluan kajian bagi mempelbagaikan kegunaan instrumen.

Kajian ini mampu menyumbang melalui analisis instrumen dapat menjadi rujukan bagi mengenal pasti faktor-faktor yang berupaya mempengaruhi kebahagiaan guru di Malaysia. Kajian ini wajar dijalankan bagi mengembangkan skop penyelidikan kebahagiaan guru di Malaysia. Pada masa hadapan, kajian lanjutan dicadangkan untuk pengkaji menjalankan kajian kebahagiaan dalam kalangan guru matematik. Kajian ini relevan memandangkan kajian kebahagiaan di Malaysia yang memfokuskan kepada guru mengikut subjek adalah sangat terhad dan terbatas dan ini jelas melalui analisis SLR yang dijalankan. Kebanyakan kajian lepas mempunyai batasan tertentu dengan mengambil kira kesemua responden guru tanpa mengira subjek yang diajar. Hal ini berkemungkin akan berlakunya kesangsian dan bias dalam dapatan kajian kerana setiap guru tidak mempunyai bebanan kerja yang sama dan tahap kesukaran setiap subjek juga berbeza-beza. Justeru, kajian ini wajar dilanjutkan untuk memberi nilai tambah kepada bidang ilmu topik kebahagiaan guru. 


\section{Rujukan}

Abdullah, A. G. K., \& Ling, Y.-L. (2016a). The Mediating Role Of Workplace Happiness On Teachers' Innovative Behavior And Affective Commitment For Malaysian Secondary Schools: A Cross-Sectional Questionnaire Survey. Teacher Education And Curriculum Studies, 1(1), 15-19. https://doi.org/10.11648/j.tecs.20160101.12

Abdullah, A. G. K., \& Ling, Y.-L. (2016b). Understanding Workplace Happiness In Schools: The Relationships Between Workplace Happiness, Teachers' Sense Of Efficacy, Affective Commitment And Innovative Behavior. Academy Of Social Science Journal, 1(4), 80-83.

Abdullah, A. G. K., Ling, Y.-L., \& Ping, C. S. (2016). Validity and Reliability of the Adopted Workplace Happiness Scale in the Malaysian School Context. Research Journal of Psychology and Educational Sciences, 2(3), 66-70.

Abdullah, A. G. K., Ling, Y.-L., Ping, C. S., \& Yusoff, Z. B. (2016). The Influence Of Workplace Happiness Towards Innovative Behavior And Affective Commitment Among The Teachers In Northern Peninsular Malaysia. RA Journal Of Applied Research, 2 (04 December), 445-450. https://doi.org/10.18535/rajar/v2i4.02

Agrawal, Anjuli \& Tyagi, P. (2016). Relation Between Happiness And Education. International Conference Proceedings N K B M G (PG) College Chandausi (U.P.), 7026, 22-26.

Al-Farabi. (1995). Abu Nashr. Arā’ Ahl al-Madīnah al-Fāḍilah wa Madlādātuhā, ver. 'Aly Bu Malham, Beirut: Dār wa Maktab al-Hilāl.

Ardiati, S. S. (2019). Effectiveness Mindful Teaching to Improve Teacher Happiness. 11(2), 109-126.

Ateerah, A. ., \& Lukman, Z. . (2019). Happiness Instrument Development. International Journal of Research and Innovation in Social Science (IJRISS), III(IV), 288-292.

Awaludin, A. (2017). Martin Seligman and Avicenna on Happiness. Tasfiyah, 1(1), 1. https://doi.org/10.21111/tasfiyah.v1i1.1840

Baltac1, Ö. (2019). The Predictive Relationships between the Social Media Addiction and Social Anxiety, Loneliness, and Happiness. International Journal of Progressive Education, 15(4), 73 82. https://doi.org/10.29329/ijpe.2019.203.6

Benevene, P., Stasio, S. De, Fiorilli, C., Buonomo, I., Ragni, B., José, J., Briegas, M., \& Barni, D. (2019). Effect of Teachers ' Happiness on Teachers ' Health. The Mediating Role of Happiness at Work. 10(October), 1-10. https://doi.org/10.3389/fpsyg.2019.02449

Bevan, S. L., Liu, J., Wallis, K. E., \& Pinto-martin, J. A. (2020). Screening Instruments for Developmental and Behavioral Concerns in Pediatric Hispanic Populations in the United States : A Systematic Literature Review. Journal of Developmental \& Behavioral Pediatrics, 41(1), 7180.

Çakır, V. O., \& Harmandar Demirel, D. (2019). A Student-Oriented Study: Analyzing the Relationship between Happiness and Satisfaction with Life. Journal of Educational Issues, 5(1), 150. https://doi.org/10.5296/jei.v5i1.14661

Centre for Bhutan Studies \& GNH Research. (2016). A Compass Towards A Juat And Harmonious Society 2015 GNH Survey Report.

Chaturvedi, M., \& Singh, A. K. (2016). Happiness: As An Aim of Education. International Conference Proceedings, N. K. B. M. G. (P.G.) College, Chandausi, 7026, 93-98.

Clemons, M. L. (2018). Relationship Between Authentic Happiness And Servant Leadership. Liberty University, Lynchburg, VA.

Clifton, J. D. W. (2014). The Eudaimonic Turn: Well-being in Literary Studies. Journal of Psychology in Africa, 24(1), 123-124. https://doi.org/10.1080/14330237.2014.906180

Elsevier. (2013). Why choose Scopus? https://www.elsevier.com/solutions/scopus/why-choose-scopus

Erozkan, A., Dogan, U., \& Adiguzel, A. (2016). Self-efficacy, Self-esteem , and Subjective Happiness of Teacher Candidates at the Pedagogical Formation Certificate Program. Journal of Education and Training Studies, 4(8), 72-82. https://doi.org/10.11114/jets.v4i8.1535

Hills, P., \& Argyle, M. (2002). The Oxford Happiness Questionnaire: A compact scale for the measurement of psychological well-being. Personality and Individual Differences, 33(7), 10731082. https://doi.org/10.1016/S0191-8869(01)00213-6

İhtiyaroğlu, N. (2018). Analyzing the relationship between happiness, teachers' level of satisfaction with life and classroom management profiles. Universal Journal of Educational Research, 6(10), 2227-2237. https://doi.org/10.13189/ujer.2018.061021 
Jalali, Z., \& Heidari, A. (2016). The Relationship between Happiness, Subjective Well-Being, Creativity and Job Performance of Primary School Teachers in Ramhormoz City. International Education Studies, 9(6), 45. https://doi.org/10.5539/ies.v9n6p45

Jones, J. P. (2010). Happiness at Work. Maximizing Your Psychological Capital for Success. In WileyBlackwell Publication (Vol. 49, Issue 6). https://doi.org/10.1108/00251741111143676

Kamthan, S., Sharma, S., Bansal, R., Pant, B., Saxena, P., Chansoria, S., \& Shukla, A. (2019). Happiness among second year MBBS students and its correlates using Oxford Happiness Questionnaire. Journal of Oral Biology and Craniofacial Research, 9(2), 190-192. https://doi.org/10.1016/j.jobcr.2018.06.003

Kashdan, T. B. (2004). The assessment of subjective well-being (issues raised by the Oxford Happiness Questionnaire). Personality and Individual Differences, 36(5), 1225-1232. https://doi.org/10.1016/S0191-8869(03)00213-7

Kim, J., Song, Y., Kim, T., \& Park, K. (2019). Predictors of happiness among older Korean women living alone. Geriatrics and Gerontology International, 19(4), 352-356. https://doi.org/10.1111/ggi.13615

Klamár, R., \& Gaval'ová, A. (2018). Regional Application Of The Gross National Happiness Index In The Context Of The Quality Of Life In Slovakia. Geographical Journal, 70, 315-333. https://doi.org/https://doi.org/10.31577/geogrcas.2018.70.4.17

Krishna K Verma. (2016). Educational Development \& Happiness in Sosiety. International Conference Proceedings N K B M G (PG) College Chandausi, 7026(16), 80-88.

Medvedev, O. N., Siegert, R. J., Mohamed, A. D., Shepherd, D., Landhuis, E., \& Krägeloh, C. U. (2016). The Oxford Happiness Questionnaire: Transformation from an Ordinal to an Interval Measure Using Rasch Analysis. Journal of Happiness Studies, 18(5), 1425-1443. https://doi.org/10.1007/s10902-016-9784-3

Mertoğlu, M. (2018). Happiness Level of Teachers and Analyzing its Relation with Some Variables. Asian Journal of Education and Training, 4(4), 396-402. https://doi.org/10.20448/journal.522.2018.44.396.402

Michalos, A. C. (2017). Education, Happiness and Wellbeing *. In Connecting the Quality of Life Theory to Health, Well-being and Education (pp. 277-299). Springer, Cham. https://doi.org/https://doi.org/10.1007/978-3-319-51161-0_12

Moher, D., Liberati, A., Tetzlaff, J., \& Altman, D. (2009). Preferred Reporting Items for Systematic Reviews and Meta-Analyses: The PRISMA Statement. PLoS Medicine; PLoS Medicine. https://doi.org/10.1371/journal.pmed.1000097

Moldovan, C. P. (2017). AM Happy Scale: Reliability and Validity of a Single-Item Measure of Happiness. Loma Linda University.

Omar, M. K., Mohd Ramdani, N. F. S., Mohd, I. H., \& Hussein, N. (2018). Organizational Happiness Index (OHI ): A Study of a Public University in Malaysia. International Journal Of Academic Research In Business \& Social Sciences, 8(11), 1984-1994. https://doi.org/10.6007/IJARBSS/v8i1 $1 / 5562$

Omar, M. K., Zakaria, R., \& Zakaria, A. (2016). Organizational Happiness Index (OHI): Conceptualization And Operationalization Of Measurement Among Employees In Services Industry. Social And Management Research Journal, 13(2), 13-28.

Panda, B. K., \& Sinha, M. (2020). Happiness Among Primary School Teachers: A Bengal Perspective. UGC Care Journal, 40(71), 3221-3237.

Piaw, C. Y. (2014). Kaedah Penyelidikan (3rd ed.). McGraw-Hill Education (Malaysia) Sdn. Bhd.

Powers, K. A. (2017). Educational Interventions to Improve Support for Family Presence during Resuscitation: A Systematic Review of the Literature. Dimensions of Critical Care Nursing, 36(2), 125-138. https://doi.org/10.1097/DCC.0000000000000228

Pratt, S. (2016). A Gross Happiness Index for the Solomon Islands and Tonga : an Exploratory Study. Global Social Welfare, 11-21. https://doi.org/10.1007/s40609-015-0041-1

Proyer, R. T., \& Gander, F. (2018). The Authentic Happiness Inventory Revisited: Addressing its Psychometric Properties, Validity, and Role in Intervention Studies. Journal of Well-Being Assessment, 77-96. https://doi.org/https://doi.org/10.1007/s41543-018- 0006-0

Proyer, R. T., Gander, F., Wellenzohn, S., \& Ruch, W. (2016). Addressing the role of personality, ability, and positive and negative affect in positive psychology interventions : Findings from a randomized intervention based on the authentic happiness theory and extensions. The Journal of 
Positive Psychology Dedicated, 9760(March). https://doi.org/10.1080/17439760.2015.1137622

Sanli, E., Celik, S. B., \& Gencoglu, C. (2019). Validity and Reliability of The Authentic Happiness Scale. Khazar Journal of Humanities and Social Sciences, 22, 5-20. https://doi.org/10.5782/2223-2621.2019.22.1.5

Seligman, M. E. (2004). Authentic happiness: Using the new positive psychology to realize your potential for lasting fulfillment. Simon and Schuster.

Sifakis, N. (2017). ELF awareness in English Language Teaching: principles and processes. Applied Linguistics, January. https://doi.org/10.1093/applin/amx034

Taghvaienia, A., \& Alamdari, N. (2019). Effect of Positive Psychotherapy on Psychological WellBeing, Happiness, Life Expectancy and Depression Among Retired Teachers with Depression: A Randomized Controlled Trial. Community Mental Health Journal, 56(2), 229-237. https://doi.org/10.1007/s10597-019-00471-z

Turner, M., Holdsworth, S., \& Scott-Young, C. M. (2016). Resilience at University: the development and testing of a new measure. Higher Education Research and Development, 36(2), 386-400. https://doi.org/10.1080/07294360.2016.1185398

Uchida, Y., \& Oishi, S. (2016). The Happiness of Individuals and the Collective. Japanese Psychological Research, 58(1), 125-141. https://doi.org/10.1111/jpr.12103

Uğur, E., Kaya, Ç., \& Özçelik, B. (2019). Subjective vitality mediates the relationship between respect toward partner and subjective happiness on teachers. Universal Journal of Educational Research, 7(1), 126-132. https://doi.org/10.13189/ujer.2019.070117

Urrutia, J. D., Borja, P. C. R., Castillo, J. C. D., \& Magana, R. A. (2019). The Relationships of Happiness and Job Satisfaction to Job Performance of Public Secondary School Teachers in Selected Schools in the Division of Cavite. International Journal of Recent Technology and Engineering (IJRTE), 8(2), 3198-3210. https://doi.org/10.35940/ijrte.B1419.0982S1119

Xiao, Y., \& Watson, M. (2019). Guidance on Conducting a Systematic Literature Review. Journal of Planning Education and Research, 39(1), 93-112. https://doi.org/10.1177/0739456X17723971

Zhang, X., Wang, Y., \& Xu, S. (2016). The Relationship between Interpersonal Relationship and the Subjective Well-Being of Chinese Primary and Secondary Teachers: A Mediated Moderation Model. World Academy of Science, Engineering and Technology International Journal of Educational and Pedagogical Sciences, 10(5), 1472-1476. 